\title{
Catholic Church and Conservative-Traditionalist Groups: the Struggle for the Monopoly of Brazilian Catholicism in Contemporary Times
}

\author{
Rodrigo Coppe Caldeira ${ }^{1}$ (D) Emerson José Sena da Silveira ${ }^{2}$ (D)
}

Received: 28 July 2021 / Accepted: 20 September 2021 / Published online: 19 October 2021

(c) The Author(s), under exclusive licence to Springer Nature Switzerland AG 2021

\begin{abstract}
The Roman Catholic Church in Latin America was crossed by numerous currents of political thought in the mid-twentieth century and early twenty-first century. A pivotal moment for the reconfiguration of the Catholic structure took place in the 1960s, with the movement of distension with modern values carried out by the Second Vatican Council (1962-1965). From then onwards, we see the resurgence of movements more to the right, anti-modern in value, although they are present in modernity. What ideas and values are the symbolic vertebrae of these Catholic movements that see Catholic tradition as a stronghold under attack? The article intends to explore the hypothesis that these traditionalist movements and groups that emerged in the second half of the twentieth century, especially in conflict with the directives of Vatican II, have values and ideas loaded with religious pessimism and political reactionarism and reflect the complex relationships between Catholicism and modernity. Based on research in primary and secondary documental sources located in the historical-sociological epistemological horizon, it is intended to present an overview of these groups, some of them more institutionalized, others more diffuse, their distinct origins, and their convergence towards a religiously traditionalist perspective while it is politically reactionary.
\end{abstract}

Keywords Modernity · Latin America · Roman Catholic Church · Traditionalism • Conservatism $\cdot$ Reactionarism

Rodrigo Coppe Caldeira

rodrigocoppe@gmail.com

Emerson José Sena da Silveira emerson.pesquisa@gmail.com

1 Programa de Pós-Graduação Em Ciências da Religião - PUC Minas, Belo Horizonte, Brazil

2 Programa de Pós-Graduação Em Ciência da Religião - UFJF, Juiz de Fora, Brazil 


\section{Introduction}

The Roman Catholic Church, especially in Latin America, went through the twentieth century shaken by a great number of challenges posed by the modern transformations of culture and society. The so-called age of grand narratives entered a crisis, emerging from it new family models, standards of morality and thought, as well as renewed social and cultural arrangements.

The pluralism of the modern world, institutionally as well as evaluatively, represents a permanent sphinx for a socio-religious system that, since its constitution at the end of the ancient Greco-Roman world, has produced the idea of "universal" and "universality" and is understood by this ontological metaphysics. In concrete historical life, however, Catholic arrangements vary historically and geographically. As Toniol and Coppe Caldeira (2020) point out, there are some patterns of structural-historical continuity. Lots of movements stand out for behaving against the tide, anti-establishment, and thus by using echoes and images of the Catholic tradition or, at least, by using a representation of such a tradition, centered on hierarchy, liturgical solemnity, and formality, on the heteropatriarchal family model and on an idea of organic connection between orthodoxy and truth. In the Western tradition, hierarchy and its sacralization have shifted from the idea of value, which is more important and central, to the idea of power and domination, which must be followed by everyone, the center of ideal political action (Dumont 1979, 1992). This last one ended up reaching prominence and has been a ram of reactionary religious movements that seek to re-establish in the world what they think is the ideal and real hierarchy, through the occupation of the state and the influence of republican powers, using, in this sense, mechanisms of liberal-representative democracy. However, it is with the acceleration of modernity, in its broad consequences, that the Church and its movements and reactions will accentuate the sacralizations of Catholic identity, which would define catholicity in the face of the world and its forms of action in the new social and political spaces that built, namely, the church-state separation and autonomy of the domains of life, understood in a Weberian sense, as sexuality-gender, science, economics, politics, and art.

In view of this, official Catholicism reacted differently, on multiple levels. In this sense, we will focus on those levels that occurred during the second half of the twentieth century. Among these levels, we will mention here the centralization of papal power, the emergence of traditionalist movements, and pressure groups that acted in society and together with the public powers, in order to guarantee influence and also some perspectives more favorable to Catholicism. It was a process that, for a wide period of time, spread across several regions and countries in which the republican state broke with Catholic hegemony, especially in the IberoLatin and European world, and sought its lay foundation. In this sense, organizations that defend a Catholicism and a Church more focused on moral issues and committed on the fronts of cultural wars, in which the theme of customs is central, can be seen as heirs of old organizations, and the recruitment of new members and the use of the means of communication became fundamental, together 
with the visibility strategies in the public sphere, such as campaigns, marches, and many others. The widespread social mediatization, if on the one hand provided weapons and strategies for these organizations, on the other hand, helped to form a kind of reactionary sensibility, embodied by figures such as priests and lay YouTubers or digital influencers. It is in this sense that this article, based on qualitative research with primary and secondary sources (digital and written), aims to build a historical-social panorama of these organizations and their main ideas in Brazil at the present time. We start from the hypothesis that these traditionalist movements and groups that originated within the twentieth-century Catholicism are responses given to modernity and reflect the complex relationships between the modern world and the Catholic world and, in a time of new illnesses, such as the one caused by the SARS-CoV-2 virus, have ideologically realigned themselves around old moral axes. On the other hand, to this restorative movement, ancient and contemporary, we can add the movement of the RCC-Catholic Charismatic Renewal and a digital fringe (social networks) with wide repercussion, composed of lay people and priests self-accepted as conservative, traditionalist, and reactionary Catholics.

It is necessary to state that every methodological choice has limitations and hermeneutic yields. To go deeper into a case or to develop a more approximate approach between several cases has limitations. It loses comprehensiveness, and generalizations become more difficult, or you gain in depth but lose in horizontal vision. Thus, we have opted in this text to make a panoramic vision about the ultraconservative movements and sensibilities in Catholicism. Thereby, we aim to discuss the reactionary and ultraconservative ideas and practices, new and old, that spread through Catholicism and are politically close to the spectrum of the rising of the radical political right in the world and in Brazil. The traditionalist and reactionary movements in Catholicism have been the subject of approaches in various fields of study and scientific disciplines, such as, for example, the sociology of religion. However, in this article, we will not make a systematic and deep review of the texts, for several reasons. One of the main reasons to not deeply review the various texts about the subject is theirfragmented character within different fields and disciplines and its use of diverse methodologies and very distinct theoretical approaches. Therefore, the object of this text is not a sociology of the sociology of religion of Catholic movements such as the TFP, Heralds, or the CCR. The main objective is to bring a more interdisciplinary vision of the aforementioned movements in their roots and in their more contemporary performance. That is why the use of primary and secondary digital and documentary sources is used, in addition to academicscientific sources from areas such as Science of Religion, History and Theology. We understand that building a good understanding of conservative Catholic associations requires a more comprehensive interdisciplinary effort. By this, we do not mean that studies from specific fields and disciplines such as the sociology of religion are not fundamental. However, our methodological choice was to broaden the dialogue to a greater gradient of authors and studies.

Nevertheless, we are careful not to fall into the risk of eclecticism. For this reason, despite being more interdisciplinary, we reduced our methodological choices to works that are fundamental for a wider understanding of Catholic movements and associations of a reactionary or conservative nature. We should, however, make 
some critical remarks about the studies of fields such as the sociology of religion, regarding the movements that we chose here as the focus of the investigation.

\section{The Church of Brazil in the First Half of the Twentieth Century: Traditionalist Bastions in Brazilian Catholicism}

The Catholic Church that entered the twentieth century in Brazil was mainly characterized by its strong re-centralization. This process, called "Romanization," took place throughout the nineteenth century and had as the main feature the struggle to maintain temporal power and the attempt to stop the influx of modern ideas in its interior, in addition to seeking greater control of religious practices in Brazilian soil. The Catholic Church in Brazil, in particular, submitted for centuries by the Portuguese patronage regime, became free in the midst of a republican state. However, with the Proclamation of the Republic (1889) and the emergence of the secular state from the new constitutional charter of 1891, the high ecclesiastical spheres realized the need to "re-catholicize" the state sphere, seeking to influence political and legal decisions through the formation of a Catholic intellectual elite, which marked the history of Catholicism in the country in the first half of the twentieth century. The emergence of the figure of Plínio Corrêa de Oliveira (1908-1995) as an important Catholic leader in the 1930s took place in this context. Through his leadership, a group was formed which radically embodied the project of the ecclesiastical summit and developed, for 3 decades, a singular path in the history of the Church in Brazil (Zanotto 2012).

The moment that demarcates the beginning of the Catholic reaction itself to the challenges of the new Brazilian political configuration was the promulgation of the pastoral letter of D. Sebastião Leme, Archbishop of Olinda and Recife, in 1916. The aforementioned pastoral letter was part of a cycle which was outlined since the beginning of the Republic, when the Catholic Church gathered forces to consolidate internal reforms, such as the recruitment of new foreign members for the religious orders, the creation of new dioceses, and the pressure on public authorities (Lima 1943).

The path to be followed, according to D. Leme, had to be the organization and unification of pressure groups, in order to demand favorable positions from the republican government on issues relating to morality, the family, and other aspects of civil life. The broad goal and costly effort for D. Leme should be, in this sense, to penetrate the main social institutions in order to imbue them with the Catholic spirit. It is clear that the Church's strategy aimed not directly at the masses, but at the elites; that happened, for example, "by establishing an important network of schools across the country that the Church counts on Christianizing the elites, so they can, in turn, be able to 'Christianize' the people, the State, the Legislation" (Beozzo 1984, p. 280). This period is called Catholic restoration (Azzi 1994). The word restoration, which came to be used by Brazilian bishops, even referred to the motto of the pontificate of Pius XI: restoring all things in Christ. The main point of the movement, according to Azzi (1994), was based on the effort for the Catholic faith to return to being one of the constitutive elements of Brazilian society. 
The idea that spread and dominated Catholic circles in Brazil was to make the country a nation explicitly oriented by Christian values. Some symbolic facts can exemplify the period, such as the institution, by Pope Pius XI, in 1925, the Festa de Cristo-Rei, the proclamation of Nossa Senhora Aparecida Conceição as the official patroness of Brazil, in 1930, and the inauguration of Christ the Redeemer in Corcovado, Rio de Janeiro, in 1931, together with President Getúlio Vargas, some ministers of state and thousands of "Catholic citizens".

During this period, but also in previous years, the Church attracted important figures of the laity belonging to the Brazilian middle class and elite to its cadres. Strictly linked to the control of the ecclesiastical hierarchy, lay movements emerged and mobilized thousands of people across the country. Of great prominence and influence was Dom Vital Center and its journal A Ordem. In addition to its founder Jackson de Figueiredo (Iglésias 1971), the relatively small group brought together a myriad of Catholic intellectuals, such as Alceu Amoroso Lima, Hamilton Nogueira, Sobral Pinto, Augusto Frederico Schmidt, Gustavo Corção, and even Plínio Corrêa de Oliveira. The center was founded in 1922 and was intended to defend the Church against liberalism, communism, and Protestantism, above all through the apology of the faith (Moura 1978; Antoine 1980).

Characterized by strong opposition to liberal ideals, the postures of The Order were identified with the ultramontane ${ }^{1}$ posture of the Church and expressive thinkers of the nineteenth century, such as Joseph de Maistre, Donoso Cortés, and Louis de Bonald. Ultramontane thought gained adherents in Brazil and was configured based on European authors who gave its initial outline, meeting and collaborating with its genesis. Marked by different nuances, obviously due to a specific historical situation, Brazilian ultramontane thought was imbued with the same fundamental goal of its European counterpart, namely: to build a social order marked by Catholic values, in which the Church would play a major role in the social arrangement.

The movements that praise a supposed immutable tradition-ultramontane, traditionalist, reactionaries, to recall the broad gradient of the socio-religious lexiconhave agitated the Brazilian Church at various historical moments and influenced political and social directions. Despite that, they have not been objects of a systematic and lasting studies of a sociology of religion, except for a few exceptions. As a structured and systematic field, the sociology of religion in Brazil is tributary to a sociology of Catholicism, especially after the profound transformations experienced from the 1950s on. Before that time, between the end of the nineteenth century and the first decades of the twenty-first century, studies focused on socio-religious processes such as the Romanization of the Brazilian Catholic Church, messianism/ millenarianism, popular/devotional Catholicism, Catholic intellectuals, currents of thought, conflicts between ecclesiastical authority, and popular experiences among the main ones (Villaça 1975). The movements we discuss here emerged, in their

\footnotetext{
1 Ultramontanism can be understood as the Catholic and political doctrine that has its main and only reference in Rome. The adjective-ultramontane Catholicism-designates, therefore, the Catholics who are in line with the directives coming from the Vatican, defending their role and domain against the affirmation of modern secular states.
} 
majority, from the 1950s to the 1970s, in a first moment and from 2000 to 2010, in a second moment, and make up to what Cândido Procópio Camargo $(1971 ; 1973)$ pointed out as one of the most important founders of the sociology of religion as a structured field of studies, called "internalized Catholicism." Catholicism was not the only subject of sociological studies of religion, of course, but it was also the nascent of the evangelical currents, the religions of the Afro-Brazilian complex, and other themes.

Religion was transforming itself pari passu to the social transformation experienced in Brazil: urbanization, conservative modernization, and sociocultural uprooting of large population contingents (internal migrations) that foreshadowed the decline of Catholicism as the driving force and matrix of the Brazilian socio-religious field (Pierucci, 2004). A whole new configuration of forces led the Catholic tradition to assume in society a more reflective form and less linked to the heritages passed from generation to generation, atavistic and naturalized, that sought to make almost synonymous, Brazilian nation/identity and (conservative) Catholicism (Pierucci 2004; Camurça 2011).

In the 1964-1985 period, of the military dictatorship, and in the period of redemocratization, sociological studies prioritized topics such as Catholicism and human rights, Catholicism and the state, Catholicism and politics, youth, and syndicalism, within which conservative movements were not always studied in a specific way (Della Cava 1975; Azzi 1977; Romano 1979). The reactionary and traditionalist Catholicism was studied a lot, in composition with a wider socio-religious picture seen as reactionary and anti-modern (Pierre Sanchis 1992 a; Montero 1999). There are exceptions, such as Lizanias (1984), Seiblitz (1991), and Antoine (1980), who worked, each in their own way, the theme of Catholic conservatism: Lizanias focusing on the biography of Plinio Corrêa de Oliveira; Antoine presenting the TFP in a panoramic way, Permanência, and Hora Presente movements; and Seiblitz dealing with the conflict in the Campos Diocese, which led to the traditionalist schism in 1988.

After the Brazilian re-democratization, the studies that took these movements as the main element, if not the only one, reflow, coinciding with the end of the military regime, the new social changes, and the entry of new actors, such as the RCC (CCR), the Pentecostal and Neopentecostal churches, and the basic ecclesial communities, among others (Camurça 2011). In the words of Pierucci $(2004,19)$ :

From the beginning, and this goes back to the 1950s, the sociology of religion practiced in Brazil was always a sociology of Catholicism in decline. In fact, not only in Brazil, but in all of Latin America that is what was observed. In all of Latin America. Even sociological studies of non-Catholic religions, if they focus on the quantitative expansion of one of them, whatever it may be, will always be doing, inside out, a sociology of the decline of Catholicism. More recently, with the reorganization of right-wing movements and their rise in the world, especially since the mid-2000s, sociological studies have begun to focus more on ultraconservative movements. Thirty-some years later, with the exception of Umbanda - which to general surprise today sees the number of adherents decreasing - the trends recorded in the early 1970s by Cândido Procópio's team are being confirmed by the 2000 census. More of the same, therefore: Catholicism is on the decline and Pentecostals and the non-religious are on the rise. 
A curious situation looms on our theme. On one hand, Catholicism lost members and saw itself reduced with each population census. On the other hand, conservative movements that defend a restrictive family-sexual morality, a clericalized church, and a resigned anti-communism, among other values, are again becoming research subjects. When this occurs, we are in the middle of an interdisciplinary field and not only in a sociology of religion stricto sensu (Romero, 2019-2020).

Thus, with the wider bibliography, we note that one of the novelties of the resurgence of the reactionary and ultraconservative Catholic element is that the circulation of its ideas is not limited to the institutional boundaries of movements and associations, but by spilling over, it points to a diffuse but visible sensibility in the Catholic Church, present in movements such as the CCR and in society. Perhaps one of the causes is the long-lasting structures that operate in Catholicism (Camurça 2011; Pierre Sanchis 1993). This can lead to terminological confusions: traditionalism, integrism, and conservatism, well addressed in a sociological text by Pierucci (1992, 147): “[...] being in fact paradoxical and mismatched in its dimensions, nothing more fair (and appropriate) than trying to account for its contradictory facets by using terms that allow more than one point of view on its disparate faces of Juno." Thus, by addressing the already named Catholic groups and the various names of their practices and ideas, it gives us a reasonable overview of how the reactionary and conservative sensibility moves and connects with the varied socio-political dimensions of Brazilian society (Almeida 2019). Next, we will look at some key characters and movements in the constitution of what today we can call Brazilian ultraconservative semantics.

\section{Plínio Corrêa de Oliveira and the Traditionalist Catholic Ideals}

To that extent, it was in the conjunctural scenario of the Catholic restoration and all the restoration efforts that Plinio Corrêa de Oliveira and his ideas emerged, marked by the total denial of any form of adaptation of the Church to modernity and its values. In Plinio's attitudes in the Brazilian lay movement and, mainly, in his writings, which range from 1930 to 1990 - when he died - it is possible to perceive an ultramontane paradigm of thought in Brazil. Plinio was the figure who catalyzed, in an explicit way, the aspirations of the restorative movement, with the intention of bringing Catholicism back to a prominent place. It could even be said that he even managed to overcome those anxieties through a more incisive perspective of defending orthodoxy. Plinio was the one who diligently developed, in Brazil, the ideas of counter-revolution, coming especially from France, ${ }^{2}$ during his life of militancy.

Plinio was born on December 13, 1908, in the city of São Paulo. His parents, João Paulo Corrêa de Oliveira and Lucília Ribeiro dos Santos, married in 1906, belonged to old families of the rural aristocracy that were formed in Brazil at the end of the

\footnotetext{
${ }^{2}$ France, which lived its revolutionary outbreak at the end of the eighteenth century, saw, in the following decades, the emergence of a quite vigorous counter-revolutionary thought, which approached, roughly, the ultramontane Catholicism and which wanted to restore the order prior to the French Revolution, marked by the monarchy and by the fundamental presence of the Catholic Church.
} 
sixteenth century and that "due to their social position and careful education can be compared to European nobility of the same period" (Mattei 1996, p.34). According to Mattei, the lawyer João Paulo Corrêa de Oliveira descended from planters in Pernambuco and Plinio's mother, Dona Lucília, from pioneers and coffee aristocrats. Therefore, it is possible to say that the parents of the future Catholic leader belonged to the high society of São Paulo of his time.

Mattei (1996) states that Plinio's spiritual learning was especially marked by the fighting spirit, which would characterize the authentic Christian life, learning from Ignatius Loyola that man's soul is a battlefield where good and evil are fighting. Indeed, Plinio "understood that the foundation of everything he loved was religion, and he chose the path of an endless struggle in defense of the conception of life in which he had been educated" (Mattei, 1996, p.53). This militant perspective that transpired in Plinio's spirit reflected well the 1920s and 1930s of the Brazilian Church, which was then on the offensive against the enemies of the Catholic faith: Protestantism, Spiritism, Freemasonry, and communism.

The outline of the formation of a group around Plinio was consolidated from his performance on various Catholic fronts, influenced by D. Leme and his restoration policy. Stimulated, above all, by the Metropolitan Archbishop of São Paulo, D. Duarte Leopoldo e Silva, the Marian Congregations movement played an important role in the conservative re-emergence that occurred in Brazilian Catholicism in the 1920s and, mainly, in the 1930s (Maia 1992). Plínio joined the Marian Congregation of the Legion of San Pedro in 1928, attached to the parish of Santa Cecilia, where he edited $O$ Legionário, a small printed newspaper. In 1929, Plínio and other prominent members of the Brazilian Catholic laity founded, in Rio de Janeiro, the Catholic University Action, linked to the Dom Vital Center. In addition, he participated in the work of Centro Dom Vital in its São Paulo strand, founded in 1931 and directed by Papaterra Limongi. He also served at the Society for Political Studies-SEP. Founded in February 1932 by Plinio Salgado, the SEP, which would become Ação Integralista Brasileira 8 months later, brought together young intellectuals from São Paulo, mainly from the Faculty of Law. This is the hard core of right-wing Catholic reactionarism, with extensive links to Italian fascism and the thought of Charles Maurras.

\section{The Legionary Group: Performance and Presence in the Catholic Panorama}

After 5 years as a Marian congregate in the Santa Cecília neighborhood, in the central region of the city of São Paulo, Plinio was invited to take over the direction of the newspaper $O$ Legionário, which was a small pamphlet at the beginning of its publication, on May 29, 1927, but that would become the official organ of that congregation. The Catholic leader took to the editorial board several prominent young people from the Marian movement and who would be in 1960, collaborators in the foundation of the Brazilian Society for the Defense of Tradition, Family and Property, the so-called TFP. Among them, we mention here Fernando Furquim de Almeida, José Carlos Castilho de Andrade, José de Azevedo Santos, Adolpho 
Lindenberg, José Fernando de Camargo, José Gonzaga de Arruda, and Paulo Barros de Ulhôa Cintra, and two young priests would mark the history of the Church of the Brazil and the world, Fr. Antônio de Castro Mayer and Fr. Geraldo de Proença Sigaud. $^{3}$ Mattei (1996) suggests that, in 1936, O Legionário, a biweekly journal with two pages, became an eight-page weekly and one of the most influential Catholic voices in Brazil. In 1937, it reached a print run of more than seventeen thousand copies (Mattei 1996). It then left its parish constituency.

Along with the news referring to the Marian Congregation of Santa Cecilia, in the journal $O$ Legionário, the main enemies and concerns of the restorative group also appeared. According to Lima (1984), the objectives of the aforementioned journal were the struggle to obtain favors from the state for the Church, the articulation of Catholic intellectuals, the surveillance of cultural production in order to identify the so called "communist infiltration," and the concern with good customs and family (conservative Judeo-Christian sexual morality). Plínio himself directed the journal O Legionário

[...] in the sense of the ideological combat that aimed[s] at raising awareness and mobilization of Catholics, reacting against the onslaught of opponents in the press and other media [...] the mission of the Legionnaire was not to "to attract unbelievers", but to guide the opinion of those who were already Catholics (Lima 1984, p.52).

The above mentioned was the great question of the Marian organ, that is, "to reach the 'educated classes' and also those 'semi-educated' [...] [should be the] main objective of the Catholic press. The role of the press in the power game was seen by $\mathrm{O}$ Legionário as of fundamental importance in the modern world" (Lima 1984, p.60). In his various texts published on the organ, Plinio, in addition to showing great concern with the press and crediting The Legionnaire with the primary task of providing Catholics with the doctrinal foundations for them to follow the straight path of the Church of Rome, pointed with nostalgia to the time when Catholic principles were hegemonic. He and his group perceived Catholic progressivism ${ }^{4}$ as a real threat that undermined the Church's authority (Coppe Caldeira 2011). The apprehension of the movements that sought to establish a bridge between the Catholic Church and modernity thus became the central concern of the group from the journal $O$ Legionário. The example of the group's understanding of the liturgical renewal of the mid-1940s reflected a whole set of ideas about Catholic Actionfounded in Brazil in 1935-that Plínio had developed and condensed in one of his most important books in defense of Catholic Action, dated June, 1943 (Oliveira 1943).

\footnotetext{
${ }^{3}$ Sigaud and Mayer played a central role in the organization of Coetus Internationalis Patrum, a group that aimed to organize the conciliar minority against liberalizing tendencies of the Second Vatican Council (COPPE CADEIRA 2011).

${ }^{4}$ It is possible to say that "Catholic Progressivism" designates those groups of Catholics who, unlike the Ultramontans, wish to establish a deeper dialogue between the Catholic institution and modern values, even allowing themselves to be permeated by them.
} 
After the death of the Archbishop of São Paulo, Dom José Gaspar de Affonseca e Silva, in 1943, who already showed concern with a certain radicalism of the movement headed by Plínio, but without taking any action against him, Dom Carlos Carmelo de Vasconcelos Motta was sworn in. The new archbishop, whose vision was contrary to that defended by $\mathrm{O}$ Legionário, proposed an armistice to the situation of conflict generated in Catholic circles since the mid-1930s and deepened with the publication of the article "In defense of Catholic Action."

Thus, in addition to the reduction in the space in which $O$ Legionário reached the dioceses, there were other facts that deserve attention: Plinio lost his position as President of the Archdiocesan Board of Catholic Action; Monsignor Antônio de Castro Mayer, one of the most important collaborators of $O$ Legionário and who had provided the imprimatur of the work, changed from vicar general of the Archdiocese to vicar economy of the parish of São José de Belém in 1945; Geraldo Proença Sigaud was removed to Spain; the various editors of the newspaper lost their positions in the Catholic movement; and, in December 1947, the collaboration of the group that followed "Pliny" in O Legionário ceased. Plínio and his group were ostracized that lasted 3 years. In 1945, they finally got together in a small house in the neighborhood of Santa Cecília, seeking to reorganize as a group.

In January 1947, the group received some news they believed to be a sign of divine providence: Father Sigaud was consecrated bishop of Jacarezinho (Paraná) ${ }^{5}$ by Pope Pius XII. The following year, Msgr. Mayer was appointed coadjutor bishop of Campos (Rio de Janeiro). In 1951, D. Mayer founded the Mensário (monthly journal) Catolicismo, which, having an editorial line similar to that of O Legionário, became the bastion of the ideas of Plinio and his followers.

The year 1959 is fundamental for understanding the path followed by Plinio in his reflections on human and Christian history. In that year, the journal Catolicismo published, in its 100th edition and at first hand, the essay by Plínio Corrêa, entitled Revolution and counter-revolution, a work that profoundly marked the history of the thought of that charismatic leader and his followers. In this work, the members of the group Catholicism saw together the essential features of their ideas and a panoramic view of the "spirit" of the struggle in which they were involved.

In July 1960, with the end of a path and the beginning of a new phase of struggle, a new chapter in the history of Plinio and his group opens: the "Brazilian Society for the Defense of Tradition, Family and Property" is founded, the TFP. The growing number of supporters of the ideas defended by that leader and his companions for Catholicism throughout Brazil led to the possibility of instituting an association capable of organizing, in a more effective way, the group's activities.

\section{The Formation of TFP: Tradition, Family, and Property}

TFP was influenced by a part of the Catholic hierarchy and ultramontane Catholicism, formed between the nineteenth century and the first half of the twentieth century. His

\footnotetext{
${ }^{5}$ Brazil is a Federative Republic formed by 26 states and the federal district, where the country's capital, Brasília, is located. Of these 26 states, 17 are coastal and 9 are inland, and they are divided into municipalities based in the city; municipalities, in turn, are divided into districts whose headquarters are villages. Brazilian territory has an extensive area of $8,514,876 \mathrm{~km}^{2}$, which comprises almost half of the South American continent.
} 
ideal embodies that of Plinio, who, from an ultramontane Catholic framework, laden with conspiratorial perspectives, aimed to defend values considered threatened, especially by "international communism" and the notion of atheism of real communist regimes (Soviet Union, Cuba, China). What would characterize the TFP, therefore, would be its new "methods of apostolate," that is, the recruitment of new adherents. In order to make himself heard in the public arena, Plínio conceived major campaigns, "in which TFP youth, through the use of megaphones, banners and slogans and songs, attracted the attention of people in the streets (Mattei 1996, p.210). He also designed "caravans," formed by groups of young people traveling around the country spreading his message. The means of communication were understood by the group as being taken over by communist sympathizers; The means of communication were understood by the group as being taken over by communist sympathizers, due to the use of "caravans", since the group aimed at direct contact with people. At the same time, Plínio wrote articles in Brazilian newspapers, especially in Folha de S. Paulo, one of the most important in Brazil at the time (Mattei 1996).

The movement TFP also regularly promoted the Anti-Communist Formation Weeks (SEFAC), which aimed to present Catholic doctrine on communism. Alongside the wide-ranging propagandist activities, it developed, in parallel, a basic apostolate, spreading Plinio's counterrevolutionary values in Christian family environments. In this context, the idea of an internal enemy was very present. Since the mid-1930s, Plínio positioned himself more and more critically of a certain Catholic hierarchy, especially that which would come to represent a form of social and progressive Catholicism, headed by D. Hélder Câmara, and its subsequent theological developments, which would lead to the formation of the so-called "Christianity of liberation" (Löwy 2000). This opposition will span the following decades and will be reactivated many times - at different times - after the re-democratization of Brazil in the 1980s, when the Military Dictatorship, fervently supported by these movements, collapsed, delegitimized, and under the weight of social and economic failure.

Thus, the TFP carried out numerous campaigns against "liberation Christianity" and its representatives, especially between the 1960s and 1970s. ${ }^{6}$ The CEBs (Ecclesiastical Base Communities), ${ }^{7}$ the most tangible expression of liberation theology, were a recurrent target of the TFP (Oliveira et al. 1982).

\footnotetext{
${ }^{6}$ In July 1968, the TFP collected more than one and a half million signatures "against communist infiltration in the Church," which sent to the Vatican received no official response. In January 1969, at the time of Archbishop Hélder Câmara's speech at Harvard, who defended China's admission to the UN and Cuba's integration into the Latin American system, newspaper articles were written against the bishop's positions, calling him to of "the red archbishop" (Mattei 1996 p. 226-227).

7 The Base Ecclesial Communities (CEBs) emerged from a new theological reading of the reality of poverty, violence, and social inequality experienced in Latin America, especially in Brazil (especially in rural regions, peripheries, and in the most impoverished geographical regions, such as the Amazon). This theological reading was called Liberation Theology and had as exponents theologians Gustavo Gutierrez and Leonardo Boff. It is a complex theology, which articulates a realistic hermeneutic perspective, inspired by the Marxist critique of capitalism. CEBs emerged at the end of the 1960s, corroborated by large conferences, such as those in Medellín and Puebla, and reached their peak between 1970 and 1985. At that time, they reached tens of thousands spread throughout Brazil. These communities consisted, in short, of groups of lay people, supported by religious and priests, who gathered to read the Bible in conjunction with the political and social reality of inequality and poverty (Gutiérrez 1979; Boff 1981, 1998; Betto 1985).
} 
Another important moment in the group's activities was the fight against "agrarian reform," proposed in 1960 by the governor of São Paulo at that time, Carvalho Pinto. The TFP published a manifesto on the front page of the most important newspapers in Brazil, announcing the publication of the work Agrarian reform, a question of conscience. The book understood that a "confiscatory agrarian revolution" was underway in the country and that, if the reform took the form proposed, the country would inevitably move towards a communist State.

The religious and political perspectives that shaped the TFP will play a prominent role in the situation that will lead the country to the civil-military coup of 1964. The imagination of the TFP-marked, especially, by the idea of an internal enemy, in the Church and in the Brazilian State-was a central element in much of the national imagination, which came to understand communism as a real threat, thus positioning itself in favor of the military. In addition to the anti-modern Catholic perspective, plus a strong anti-communist ideal, it is important to point out, at least briefly, a certain "mystical TFP" that developed in the group's history (Zanotto 2012). Marked by a considerable Marian devotion, particularly of Fatima and its messages, ${ }^{8}$ Plinio understood himself as a prophet in charge of providing for a particular mission. Because of this, his followers should have a deep reverence for him.

According to the testimony of an egress member of the TFP, the height of this attitude would be when the adept felt able to say: "It is not I who live, but Plinio who lives in me" (Folena apud Zanotto 2012, p.233). Plinio saw himself, and was understood, as a "prophet" of a new Christendom, in the future Kingdom of Mary to be instituted. It can be said that such mystic took on eschatological and millenarian elements, since Plinio's mission was:

[...] announce the triumph of the counterrevolution he providentially led [...] which, after an intense battle with the forces of evil [...], will finally be victorious, thus realizing eternal salvation with the elevation of nature of the "elects" and the condemnation of the ungodly, as well as establishing a new sacred era: The Kingdom of Mary (Zanotto 2012, p.250).

From this conservative Catholic scenario, with mystical touches, new facets of contemporary Brazilian Catholic traditionalism are designed.

\section{New Facets of Contemporary Brazilian Catholic Traditionalism}

The radical Brazilian "Catholic right" found new forms of association and reproduction based on traditional organizations, some of them arising from internal splits that affected organizations such as the TFP and its members. However, the

\footnotetext{
8 According to tradition, Our Lady would have manifested in 1917, in the city of Fátima, in Portugal, to three children, transmitting to them three secrets, which were partially revealed in the twentieth century. One of the secrets told about the communist expansion around the world and the persecution of Christians.
} 
strength of the conservative Catholic imagination remained a pole of attraction for new members. As Catholicism declined as a social force and as a religion, these groups acquired new forms of action and visibility, including on electronic social networks.

In this context, two associations emerged directly from the TFP's internal conflicts: the Associação Cultural Monfort and the Heralds of the Gospels, both founded by former members who, in general, disagreed with the mystical cult surrounding its founder, Plínio Corrêa de Oliveira, and the form of administration of the group established by him. A history professor, Orlando Fedeli, and a priest, João S. Clá Dias, made a monsignor in the 2000s by Pope John Paul II, are considered founders of these two organizations. They are based in the city of São Paulo, but they develop activities throughout Brazil, especially through electronic networks.

The TFP, in the early 2000s, was weakened: members prevented by court decision from using the name "tradition, family, and property"; deprived of many of their younger followers by a split that followed the death of the organization's founder in 1995; and defeated by splinter groups in similar disputes in at least 7 of the 16 countries where the TFP had representatives at the time of the founder's death. Thus, in the 1990s, split-up and litigation processes began to take place in other countries where the TFP also operated (Canada, Colombia, Ecuador, Bolivia, Argentina, Uruguay, and Spain).

\section{Heralds of the Gospel}

In Brazil, a legal dispute began in 1997-and it can be said that it has not ended yet-which culminated in the victory of a dissident group, led by Monsignor João Scognamiglio Clá Dias. This cleric demanded in court the right that the organization's decisions were not taken only by the small group of, then, eight remaining founding partners of the TFP. Clá Dias and his followers were accused by the founding partners of giving a "coup" to the TFP, taking control of the entity and abandoning the radical political militancy of the right to private property and the fight against left-wing social movements. The goods (real estate and property) and finances of the old TFP, which are many, passed, for the most part, into the hands of the new association, the Heralds of the Gospel.

Later, in 2001, the members of the Association of Heralds of the Gospel were present in the Hall Paul VI: John Paul II recognized as being of Pontifical Right, the International Association of the Faithful, Heralds of the Gospel. It was the first pontifical approval of the millennium, from which more others would come. ${ }^{9}$ One of the cardinals present at the ceremony, Jorge Maria

\footnotetext{
${ }^{9}$ Check link: http://www.arautos.org/noticias/56354/22-de-fevereiro--ha-13-anos-atras-Beato-JoaoPaulo-II-aprovava-e-reconhecia-os-Arautos-do-Evangelho.html. Accessed on: February 20, 2014.
} 
Mejía, reportedly said that the Heralds of the Gospels would be "the arm of the Pope". ${ }^{10}$ Some would say that it is a right-hand man to fight against modernity and the profound social and cultural changes that came with it. Between 2004 and 2006, the founding partners and their followers ended up leaving the former association and started to be called the "TFP Founders Association." In 2008, a new decision banned the use of the acronym TFP by the founders. They then called themselves the "Founders' Association."

In fact, the emergence of this new association meant the silencing of right-wing political campaigns and invested strength in defending conservative sexual morality, in Marian devotion and in its internal growth and strengthening, organizing houses, recruiting new members, and approaching bishops and conservative priests, among other common practices.

The followers of João Clá Dias are present today in 78 countries; they grew, expanded, and specialized their activities with the creation of two organizations linked to the Heralds of the Gospel. In 2006, under the pontificate of Benedict XVI, two other societies of Pontifical Law were created: the Virgo Flos Carmeli ${ }^{11}$ society, dedicated to the formation of priests, which, according to the association's data, now exceeds a hundred, and the Regina Virginum Society of Apostolic Life, ${ }^{12}$ aimed at women of consecrated life.

The society, dedicated to the formation of priests, has 3 churches dedicated to this activity: Nossa Senhora do Rosário Church, in Caieiras, São Paulo; the San Benedetto in Piscinula Church in Rome, Italy; and the Nuestra Señora de la Encarnación Church, in Lima, Peru. The female society, on the other hand, has a central house, Casa Monte Carmelo, in the city of Caieiras, São Paulo; the Casa Cenáculo, in Tremembé, São Paulo; Casa Santa Teresa, in Nova Friburgo, Rio de Janeiro; Casa Santa Joana d'Arc, in Campos, Rio de Janeiro; and the Casa Regina Virginum, in Guatemala.

Pontifical approval was granted to them by Pope Benedict XVI, in an audience held in April 2009, led by cardinal D. Franc Rodé, and then Prefect of the Congregation for Institutes of Consecrated Life and Societies of Apostolic Life. The role of these cardinals was to mediate the relationship between traditionalist groups and papal approval, thereby gaining recognition and authorization. Among the activities of these two societies are attending confessions in a parish in the city of São Paulo, religious assistance in hospitals, the making of books (they have a publishing house, Lumen Sapientiae), and the journal Arautos do Evangelho. ${ }^{13}$ In addition to these societies, the St. Thomas Aquinas Theological Institute (ITTA) and the Aristotelian-Thomist Philosophical Institute (IFAT) were created, properties of the Clerical Society of Apostolic Life of Pontifical Law Virgo Flos Carmeli, dedicated to train

\footnotetext{
10 Check link: http://www.arautos.org/noticias/56354/22-de-fevereiro--ha-13-anos-atras-Beato-JoaoPaulo-II-aprovava-e-reconhecia-os-Arautos-do-Evangelho.html. Accessed on: February 20, 2014.

11 Check link: www.virgofloscarmeli.org/page/artigo/25289 http://www.arautos.org/view/show/341arautos-do-evangelho. Accessed on: February 21, 2014.

12 Check link: http://www.reginavirginum.org.br/brasil/home.asp. Accessed on: February 21, 2014.

13 Check link: http://www.virgofloscarmeli.org/page/artigo/27309/Atividades. Accessed on: February $21,2014$.
} 
students in theology and philosophy, thus becoming the formation house for future priests and sisters of consecrated life. ${ }^{14}$

Some say that the Church hierarchy's discomfort with protests by Plinio Corrêa de Oliveira, since the 1970s, led to the support of bishops, Pope John Paul II and Benedict XVI to the group led by João Clá Dias. The old TFP, in addition to an ultra-traditionalist direction, close to the schismatic groups, developed a mystical cult of the founder, who saw him as a new prophet and a divine choice. The Heralds of the Gospel do not hide their sympathy for prayers in Latin, for the revaluation of traditional adoration of the Blessed Sacrament, and for the defense that Communion must be received in the mouth and on our knees, among other aspects. Depending on the perspectives of understanding, these can be signs of traditionalism, conservatism, reactionary spirit, or anti-modernism. What actually happens is that the dissemination of the Heralds of the Gospel had a great reach, being supported by many Brazilian bishops who delegate churches and spaces to the heralds to be managed and used by them. ${ }^{15}$

The Heralds of the Gospel are extremely organized and disciplined; they invest in social media, even having an online TV channel (on YouTube) and an official profile on Facebook. This set of actions and investments is called Herald Media, ${ }^{16}$ which demonstrates a new facet of Catholic conservatism that has been emerging: with an organized, systematic, and rational investment (with the help of professionals linked to communications and marketing) in old and new media (especially electronic social networks). Along with this, they adopt an outfit worn by lay people, priests, and women of consecrated life. Among the items in this garment are boots, rosary, cloaks, and garments in brown, red, and purple with a stylized cross, recalling the symbols of the Medieval Crusades.

The Heralds work diligently in their social reproduction, that is, in recruiting members, including the formation of priests who is extremely attached to the group's values. Currently, they have two seminars: the São Tomás de Aquino Seminary, in a small city in the state of São Paulo, and the Santiago Seminary, in the city of Tocancipá/Cundinamarca, in Colombia.

Perhaps one of the association's best known and most public activities is the celebration of masses in Latin. Second document of the association, accessible electronically:

From then on, we started to dedicate ourselves to spreading the Gregorian Mass throughout Brazil, collaborating with all those who wanted the Mass in this rite. This collaboration extends to many activities, among which we highlight the teaching of Latin, Gregorian, making booklets to accompany the Mass, classes on the Tridentine rite, obtaining vestments and liturgical material for priests, awareness of priests about the importance to respond to the requests of the faith-

${ }_{14}$ Check link: http://www.virgofloscarmeli.org/page/artigo/27174. Accessed on: February 21, 2014.
${ }^{15}$ Check link: http://www.arautos.org/artigo/411/Casas-no-Mundo.html. Accessed on: May 10, 2015.
16 Source: http://www.arautos.org/view/show/341-arautos-do-evangelho. Accessed on: May 10, 2014. 
ful, to organize visits by priests who already celebrate the extraordinary rite for those who wish to learn this rite, etc. Our work ended up sensitizing many clerics and reached practically all the main capitals of Brazil and several cities in the interior of the State of São Paulo. Today we can see that we collaborate in the realization of most Masses celebrated in the Tridentine rite. ${ }^{17}$

The liturgical issue, that is, the mass in Latin, is an element that maintains Catholic conservative and traditionalist organizations around a common front, liturgical formalism, but the axis of hierarchy, centered on the issue of the family, of anticommunism (an extremely flexible label), anti-gay, anti-state, and anti-abortion, although there are tones and overtones within the movements.

\section{Montfort Cultural Association}

A former member of the TFP, Orlando Fedeli, professor of history, founded, in 1983, an association of lay Catholics based in the city of São Paulo, called "Associação Cultural Montfort." According to the statement of principles formulated by them, "the group considers itself linked to the guidelines of Dom Antônio de Castro Mayer (excommunicated by Pope John Paul II, together with Bishop Lefrève), assuming the defense of the Tridentine rite". ${ }^{18}$ The reason for being, indicated by the documents produced by the association, all available on the electronic portal, ${ }^{19}$ is the defense of the Catholic Church and its teachings, in particular, against the "modernisms" disseminated after the Second Vatican Council.

The choice of the name, according to the association, was due to a tribute to two European characters, a saint and a French-Norman leader: São Luís Maria Grignion de Montfort (1673-1716), a great defender of Marian devotion, and Simão de Monfort (116?-1218), who led the crusade against the Cathar sect in the Middle Ages. Among its main activities are the holding of lectures, congresses, weekly meetings at the headquarters, in the city of São Paulo, and through the electronic portal that is kept up to date even after the founder's death, which occurred in $2010 .{ }^{20}$ As a matter of fact, with his death, the direction passed to his wife, assisted by leaders elected from among the associates, who number in the thousands throughout Brazil. The members recruited by the Montfort Association come from a wide variety of backgrounds, particularly university and student groups.

Their method of dissemination is called apologetic and consists of exposing Catholic doctrine (in disagreement with the Second Vatican Council), by repeating the teaching of Thomas Aquinas and some encyclicals and other papal documents, notably those that sought to combat modernism. However, despite the supporters of the mass in Latin and other traditionalist aspects mentioned above, its members

\footnotetext{
17 Check the link: http://www.arautos.org/noticias/56354/22-de-fevereiro--ha-13-anos-atras-Beato-JoaoPaulo-II-aprovava-e-reconhecia-os-Arautos -of-the-Gospel.html. Accessed on: February 20, 2014.

18 Source: http://www.montfort.org.br/quem-somos/. Accessed on: February 20, 2014.

19 Source: http://www.montfort.org.br/. Accessed on: February 20, 2014.

20 The portal is at this address: http://www.montfort.org.br/.
} 
resort to the documents of the Second Vatican Council to defend themselves from criticism and attacks:

The ideas expressed on this site are the sole responsibility of their authors, who are, like all members of the Montfort Cultural Association, lay Catholics. In this condition, the contributors to this site never have any pretension to speak on behalf of the Holy Church, but only seek to defend it and spread what it has always taught, in a faithful and submissive way to the ecclesiastical Magisterium. Lay Catholics who write on this site exercise a duty and a right, as, incidentally, has been recognized even more recently by the Second Vatican Council — which we cite as an ad hominem argument — by expounding the duties and rights of the laity, saying: "all lay people, therefore, bear the clear burden of working so that the divine plan of salvation may reach ever more all men at all times and in all places on earth. Consequently, let them be given ample opportunities so that they too may actively participate in the saving work of the Church, in accordance with their strength and the needs of the times" (Vatican II, Lumen Gentium, n. 83). ${ }^{21}$

Finally, according to the association's discourse, member couples are encouraged to have a large family, that is, many children. Later, some of these children are dedicated by their parents to the priestly life. ${ }^{22}$

Among other points in common with the Heralds, in addition to the "defense" of the Catholic faith, is the appreciation of music and art, with the organization of choirs and bands, in the classical style. The point of convergence of these conservative groups is the liturgy. And this became recognized when Benedict XVI released the "old mass," without the express authorization of the bishop, with the motu proprio Summorum Pontificum, 2007. Ratzinger intended to continue the pastoral policy of John Paul II and to heal the schism of 1988, and this from the liturgy, one of the nodal points for traditionalists. In this sense, the schismatics, who wished to return to the Catholic Church, could be received with a peculiar status. This inclusive action allowed, in one of the dioceses that joined the 1998 schism, there were returns. Thus, the Apostolic Administration of St. John Mary Vianney emerged.

\section{Apostolic Administration St. João Maria Vianney}

Catholic traditionalism, as a reaction to the Second Vatican Council, was the cultural environment that made possible the emergence of the Apostolic Administration of St. João Maria Vianney. The main bastions of this movement are the figure of the Bishop of Campos, D. Antônio de Castro Mayer, who, together with Marcel Lefebvre, were excommunicated, in 1988, for having radicalized the discourse against the conciliar determinations-especially, because they had consecrated four bishops without permission from Rome. This led to a direct confrontation; in 1988,

\footnotetext{
${ }^{21}$ Letter at the link: http://www.montfort.org.br/nota-de-esclarecimento/. Accessed on: February 20, 2014.

22 Source: http://www.montfort.org.br/quem-somos/. Accessed on: February 20, 2014.
} 
Pope John Paul II excommunicated them. Note that between 1965, when the conciliar resolutions were promulgated, and 1988, this group followed the Tridentine liturgy (Masses in Latin) and the previous pastoral (women wearing veils, priests in black cassocks), something based on Vatican I and on Council of Trent (Catholic Counter-Reformation).

Note also that the popes and the Vatican Curia tolerated the activities of this group. This traditionalist group, aiming to grow with the ordination of more bishops and priests, was excommunicated. However, when Ratzinger rose to the papacy, there was a strong conciliatory policy with dissident and schismatic groups. From then on, part of the excommunicated dissidents from the Diocese of Campos, in the state of Rio de Janeiro, began to approach the Vatican. In 2001, the Pope wrote a letter to the group:

In view of these considerations and for the greater glory of God, the good of the Holy Church and that supreme law which is the salus animarum (cf. can. 1752 CIC), affectionately accepting your request to be received into the full communion of the Catholic Church, we canonically recognize your belonging to it. At the same time, we communicate to you, Venerable Brother, that the legislative document that will establish the juridical form of recognition of your ecclesial reality in order to ensure respect for your peculiar characteristics. In this document, the Union will be canonically erected as an Apostolic Administration, of a personal character, directly dependent on this Apostolic See and with territory in the diocese of Campos. It will be a cumulative jurisdiction with that of the local ordinary. Your government will be entrusted to you, Venerable Brother, and your succession will be assured. The power to celebrate the Eucharist and the Liturgy of the Hours in accordance with the Roman Rite and the liturgical discipline codified by our predecessor Saint Pius V, with the adaptations introduced by his successors up to Blessed John XXIII, will be confirmed to the Apostolic Administration. It is, therefore, with profound joy that, in order to make full communion effective, we declare the remission of the censure established by can. 1382 CIC in what concerns you, Venerable Brother, as well as the remission of all reproaches and the dismissal of all irregularities in which other members of the Union have incurred. ${ }^{23}$

A year later, in 2002, Pope John Paul II issues the Decree of Erection of the Apostolic Administration (Animarum Bonum), which, among other things, decrees:

I - By special mandate of the Supreme Pontiff, by Decree of the Congregation for Bishops, the Personal Apostolic Administration of St. John Maria Vianney is created, which covers exclusively the Diocese of Campos, in Brazil, equated by law to those dioceses immediately subject to the Holy See.

II - Personal Apostolic Administration St. John Mary Vianney, governed by the norms of common law and by this Decree, and is subject to the Congrega-

\footnotetext{
${ }^{23}$ Documents related to this process are available at: http://www.adapostolica.org/novo/documentos-daerecao-canonica-da-adm-apostolica/. Accessed on: February 20, 2014.
} 
tion for Bishops and to the other dicasteries of the Roman Curia, according to the attributions of each one.

III - The Apostolic Administration is entitled to celebrate the Holy Eucharist, the other sacraments, the Liturgy of the Hours and other liturgical actions according to the rite and liturgical discipline, as prescribed by Saint Pius V, together with adaptations introduced by his successors until Blessed John XXIII.

IV - Personal Apostolic Administration Saint John Maria Vianney is entrusted with the pastoral care of an Apostolic Administrator, as his own Ordinary, who will be appointed by the Roman Pontiff in accordance with the norms of common law.

Although officially confined to the Diocese of Campos, the group extended its activities in the form of spiritual assistance to other parishes and communities in which it celebrated the Masses of the Rite of Pius V (A MISSA... 2005). Thus, in November 2002, another document was issued authorizing activities outside the diocese:

1. With regard to communities of faithful linked to the preceding liturgical tradition, possibly residing in the territories of the dioceses, belonging to the ordinary competence of each diocesan Bishop, to grant, to the faithful who request it and in the churches specially indicated by the Ordinary, the use of the so called the rite of Saint Pius V, according to the liturgical discipline approved by Blessed John XXIII in 1962. To receive such a concession, these groups of faithful must formally declare their adhesion and obedience to the Holy Father John Paul II, recognize the validity of the Ecumenical Council Vatican II and the legitimacy of the liturgical rite approved by the Supreme Pontiff Paul VI in 1970 (cf. John Paul II, Motu proprio Ecclesia Dei adflicta, 2.7.1988, AAS 80 [1988] 1495-1498; Congregation for Divine Worship and Discipline of the Sacraments, Circular Letter Quattuor abhinc annos, 3.10.1984, AAS76 [1084] 1088-1089). ${ }^{24}$

With the blessings of Rome, one of the priests linked to this group was ordained a bishop: Dom Fernando ArêasRifan (2005). ${ }^{25}$ From this policy of approaching schismatic conservatives, the leadership of this bishop grew so much that, in 2014, they had a team of 32 priests and monsignors, maintaining an electronic page that presents the main documents, activities, and proposals of the group. ${ }^{26}$

The basic area of action is the Diocese of the city of Campos, where they have 6 parishes and rectory and serve 6 nearby cities, with one parish each. Outside the Diocese of Campos, they serve several communities in other cities in Rio de Janeiro

\footnotetext{
${ }^{24}$ It can be found at the link: http://www.adapostolica.org/novo/documentos-da-erecao-canonica-daadm-apostolica/. Accessed on: February 20, 2014.

${ }^{25}$ It is found in the document written by the bishop and which brings the main lines of understanding of the Apostolic Administration.

26 Available at: http://www.adapostolica.org/novo/documentos-da-erecao-canonica-da-adm-apostolica/ Accessed on: February 20, 2014.
} 
(the capital and other large cities), São Paulo (the capital and 2 other cities) and Minas Gerais (the capital and 4 other cities). Their activities are also registered in electronic social networks, such as YouTube. ${ }^{27}$ In this measure, among the most important functions of this group is the celebration of masses in Latin, the teaching of Tridentine rites and Latin itself, the activities confession and spiritual direction, and the recruitment of youth and other members.

\section{Catholic Neo-reactionaryism: Derivations and Importance for Brazilian Catholicism}

The axes of action of all these Catholic movements operate outside the CNBB, official spokesman for Brazilian Catholicism, and remained basically identical even though the serious disease caused by the new coronavirus befell Brazil.

The official hierarchical Catholic body, the CNBB, however, frequently speaks out, expresses agreement with the papal concerns about the environment, social justice, and care for the poor and indigenous, close to the Catholicism side of the justice and social equality; recommends the adoption of measures by international health agencies; and, finally, accepts the restrictive measures to combat the new coronavirus. The scenario of conflicts between health guidelines and public policies around the fight against COVID-19 has accentuated the disputes for an ideal representation of what "Catholicism" is in the public space between the instances of Catholic grouping, namely, the CNBB, the traditionalist and conservative movements, seen above, and a certain neo-reactionary Catholicism, expressed by groups linked to the RCC-Brasil.

The CCR (Catholic Charismatic Renewal) movement today echoes several banners long cherished by Brazilian Catholic traditionalist and conservative movements. All are in tune with right-wing populist governments and policies that rose to power in the world and in Brazil as of 2018. But, we need to elaborate a qualification of the neo-reactionary leadership of Brazilian Catholic charismatics, in particular. Since its beginning, in the years 1966/1967 in the USA-American universities-the movement was influenced by Pentecostal practices and beliefs that have spread since the beginning of the twentieth century in diverse and extensive waves. In the 1960s, these waves spread and reached historic churches, including the Catholic Church. The movement expanded and arrived in Brazil between 1969 and 1970 in the region of Campinas, São Paulo, during the Military Dictatorship (1964-1985) and became one of the greatest forces of Brazilian Catholicism, building a wide structure. Initially, it was organized into prayer groups and life and covenant communities but always based on the Catholic ecclesial structure (parishes, dioceses, priestly hierarchy) but at the same time creating organizational instances (councils, associations, ministries) (Prandi 1997; Carranza 2000; Silveira 2008a, b; Procópio 2012, 2019).

We propose a reading of Brazilian charismatics in four moments: wild charisma (1969-1990), domesticated charisma (1990-2002), politicized charisma

\footnotetext{
27 Video commemorating 10 years of documents of acceptance and episcopal ordination of Dom Fernando Rifan: http://www.youtube.com/watch?v=I89V-R4KMzs. Accessed on: February 20, 2014.
} 
(2002-2010), and reactionary charisma (2010-2020). The notion of charisma goes back to Weberian contributions, from the idea of its irruption as an anti-rationalizing force to its bureaucratization and routinization changing route and quality. At each moment, we have forces in disputes and groups that become hegemonic over time, while others lose space and power, becoming the minority. For example, in 1994, there was a Catholic centralization (purging of Pentecostal and autonomist tendencies) promoted by the CNBB, expressed in document 94 (Pastoral Guidelines on Catholic Charismatic Renewal), and approved at the 34th ordinary general assembly and, later, from the mid-2000s onwards, the reactionarization of charisma (far-right with fascist tones), an attempt to rearrange hierarchy and holism (the old catholic totality) in a modern society of liberal and individualistic values covered by liberal-representative democracy. From the first to the fourth moment, it can be observed an escalation of some elements: the valorization of ecstatic charismatic experiences (extraordinary gifts of the Espírito Santo/Pentecost); the mystical bodily technical subjectivity; the ecumenical gestures (friendly coexistence with Pentecostals and Protestants); non-involvement with party politics; less moralists lose space and accentuated bureaucratization; Catholicization and politicization of charisma; moralistic subjectivity; verticalized experiences (hierarchies and commandments); emphasis on Catholic signs (prayer of the rosary, devotion to saints , Catholic Church defended as unique and universal); and strong corporate-political and reactionary-conservative performance.

The outline of this text is, therefore, on the last two moments because they converge to reactionary anti-modern world ideas. From 2010, we have a strong entry into the Brazilian public space from politics, election of representatives in the National Congress, an alliance with traditionally conservative Catholic segments, and the adoption of an exclusivist-war theology. In the eyes of many charismatics, a true religion finds itself in a war against destructive global dimensions, which is commanded by the UN (United Nations) and financed by the "perverse", "globalist" elite that intends to impose a liberalprogressive- green agenda such as "gender ideology", same-sex marriage, global warming, sex-gender diversity since elementary school. Therefore, in a charismatic point of view, the troops of faithful must be religiously furnished in order to achieve effective political results. Since then, the movement has echoed Trumpism and Bolsonarism in campaigns against homosexual marriage, against abortion, against communism (cultural Marxism), against globalization ("globalism," in the politicalreligious language of this segment), and in the occupation of the state apparatus (executive, judiciary) by declared Christians (Catholics and evangelicals) in function of a "nation project," which has two paths, the recovery of a lost greatness ("Make America Great Again") and the vocational realization ("Brazil above all, God above all").

The lineages that set off this reactionary revolt against representative liberal democracy are not new, neither in the USA nor in Brazil. The communicating lines of conservative-reactionary values and practices circulate between an American and a South American point. Of so many lineages, one of the most pulsating, chosen by Steve Bannon and Olavo de Carvalho, spiritual mentors of the extreme right in the USA and Brazil, and the movements associated with them, Trumpism and "Bolsonarism," for example, is the "cultural war" and that of "cultural Marxism," labels that will cover wide spectrum of reactionary campaigns and religious infiltration 
actions of the Christian right in republican state powers (Hunter 1991). A broad ideological-institutional arc supports these ideas in Brazil: the president's guru and his family, Olavo de Carvalho, deputy Marcel Van Hattem (Partido Novo), the Liberal Institute, the proponents of Escola sem Partido (a movement with religious bases evangelical Christians and Catholics who between 2010 and 2020 tried to implement changes in the legislation, but was defeated by the STF), Catholic priest Paulo Ricardo, Jair Bolsonaro and members of his government as the most Trumpist-Olavist-Catholic of them, and the former minister of foreign relations, Ernesto Araújo.

In the field of institutional and official manifestations of Brazilian charismatic Catholicism, for example, it is possible to find, in a diffuse and diluted way, the echoes of trumpist ideas on the ideological bases that link it to "bolsonarism", such as: the idea of a Christian nation, anti-communism, anti-intellectualism (global warming, covid-19), traditionalfamily values (white, Christian, heterosexual, patriarchal). In the corporate-electronic portals of the national RCC, Canção Nova and their social media, we do not identify explicit defenses of right-wing populist ideas There are clear indirect and diffuse links, however based on the defense of the traditional values of the Church (Silveira 2019; Silva and Silveira 2020).

The mobilization that is a little more explicit takes place around the moral axis and results from the election of some deputies and councilors whose artifice is the work of the Ministry of Faith and Politics (MPF), institutional segment of the RCC-Brasil. The powerful action takes place on three fronts: the organization and internal systematization in front of Catholic instances, the training of conservative Catholic professionals, especially in the legal sector (responsible for the interpretation/application of laws), and the bet on the election of charismatic politicians. The bills of charismatic state and federal deputies meet the moralist-conservative-reactionary banners and corporate agendas (Procópio 2015; Pátaro et al. 2019; Silveira 2008a, b).

The moments in which the echoes of the radical right crystallize are due to media-spectacular personalities, such as bloggers Bernardo Küster and the priest performance, Paulo Ricardo. Both maintain powerful social networks that, combined, form thousands of followers, shares, comments, and millions of video views. The two reactionary Catholics represent two lines of action, a more religious one, with political intermediaries, and a more political one, with religious intermediaries. In this last line, anti-communist beliefs are revamped: the COVID19 virus would be a Chinese biological weapon produced with the intention of weakening the Christian West and part of a great project of global communist domination, or of a new world order carried out by companies like the Huawei. In the "Community" section of his YouTube channel, Küster, who calls himself an essayist, translator, and journalist, echoes reactionary and radical right ideas: In the "Community" section of his YouTube channel, Küster, who calls himself an essayist, translator, and journalist, echoes reactionary and radical right ideas. In May 2020, this banned Catholic blogger published a video titled "Big day! —New Min. of Health, Chloroquine released, Regina leaves and Trump summons OMS" (Silva and Silveira 2020). One indeed can see there some enthusiastic apology of the president Bolsonaro.. One indeed can see there some enthusiastic apology of the president Bolsonaro. 
The circulation and penetration of Trumpist ideas in the Catholic milieu can be seen among great white, Catholic, and middle-class pop stars, but they are also present among small and almost invisible conservative missionaries, such as "Rafael Arcanjo de Maria," a young man black, self-styled "catholic, sinner, businessman." Owner of a YouTube channel with just over one thousand four hundred subscribers and adorned with the invective Latin phrase "Roma Locuta Est, causa Finita Est," "Arcanjo de Maria" published in June 2020 a video titled "Coronavirus-One of the Pillars for Implementing the New World Order." In this video, the coronavirus is part of a Chinese plan to become the world's greatest power. We will not have space to explore, but there is a hypothesis to consider for the search for reactionary hegemony and its proximity to the ideological bases that support Trumpism and Bolsonarism: the reactivation of the middle class discourse of politics as an exclusive field for the fight against corruption and the evil. This led the charismatic-Catholic movement to approach the conservatives (anti-communism, traditional family values, Christian nationalism) which pulsed latently in broad sectors of the Brazilian right, in particular, São Paulo, where the RCC was baptized. Here, too, we have a situation of multiple hegemonies: the hegemony of bureaucracy and the ideas of charismatics from São Paulo, the hegemony of the conservative-moralist discourse, the hegemony of the white and middle classes, and the hegemony of political engagement in a cultural war. This is what we can think of articulating and crossing ideas, data, and information by Oliveira (1978), Pierucci (1987), Machado (1996), Prandi (1997), Carranza (2000), Reis (2011), and Procópio (2014, 2019). They were members of the charismatic movement in São Paulo and the middle class who supported President Collor de Mello and against his impeachment process (1992) and the governments and candidates of the PSDB (Brazilian Social Democracy Party), distrust and opposition to the governments of left (Lula and Dilma, between 2002 and 2016), judge Sérgio Moro's campaign, and the declared and enthusiastic support for Jair Bolsonaro's campaign in 2018. The traditionalist/conservative and charismatic segments of Catholicism continue to support the federal government, seeking political agreements that caused strong controversy with the CNBB (National Conference of Bishops of Brazil) and cultivating the populist ideals of the radical right. What can be observed are two types of beliefs and ideas, personified in more conservative / reactionary groups. In general, they are indifferent to or despise the new coronavirus, approaching right-wing populist governments. In some cases of far-right ideals, and of groups more attentive to global health standards and to the social and human impacts of the pandemic, thus keeping their distance from governments that despise the deadly impacts of Covid-19.

\section{Final Considerations}

In all Catholic groups presented in this article, we can observe expressions of a Catholic traditionalism that remained in communion with Rome, having as its main characters Plinio Corrêa de Oliveira, founder of the Association for the Defense of Tradition, Family and Property; Orlando Fedeli, a egress member of the TFP who created the Montfort Cultural Association; Clá Dias, also a egress member of the 
TFP and founder of the Heralds of the Gospel; and D. Fernando Areas Rifan, bishop and apostolic administrator of the Diocese of Campos.

These groups, adversaries among themselves, due to the misunderstandings of their founders and the methods of administration, even asserting themselves in strict obedience to Rome, reveal continuous criticism of Vatican II in some of its aspects. Some more, like Montfort, others less, like the Heralds. However, it is possible to affirm that these groups participate in a contemporary reactionary horizon, that is, they are groups linked to an idealized past time and wishing to return to it.

On the other hand, with the emergence of organized groups, such as evangelicals and some Catholic sectors, there is an increasingly clear conflict between an understanding of tradition, understood in relation to an imaginary past that must be preserved, and modernity, taken together as some cultural forces for the disintegration of that world and which should be fought.

The consolidation of these groups took place in the papacies of Karol Wojtyła and Joseph Ratzinger, when the Vatican took pains to create administrative-liturgical solutions to house groups of former schismatic dissidents. The structure of these organizations is peculiar, some of which are directly linked to the Vatican (private associations of the faithful). The pastoral policy of inclusion had as its high point the document Summorum Pontificum, promulgated by Benedict XVI in 2007, authorizing the Tridentine Mass without the need for the bishop's consent and equating it to a series of special liturgical rites, recognized as Church heritage Catholic-Chaldean rite, Maronite rite, Melkite rite, and others.

We can observed that both the Heralds of the Gospel and the Monfort Association and São João Maria Vianney Administration are close, at least in terms of "ideological" and/or cultural similarities, of traditionalist groups detached from the Catholic Church, opposing each other, in to a greater or lesser degree, to the Missal of Paul VI (1969), denying the conciliar conception on the issue of religious freedom and having as its main support the encyclicals and pontifical documents of the nineteenth and early twentieth century, such as the Syllabus Errorum Modernorum and the encyclicals Mirari Vos Arbitramun and Quanta Cura.

It should also be noted that the possibility opened by the authorization of masses in Latin without the bishop's authorization has been used by some traditionalist groups as a breach through which they attack the legacy of the Second Vatican Council, asking for its complete annulment (Faggioli 2012). Remarkable perspectives of these groups are the eschatological and the persecutory, leading them to understand themselves as persecuted movements because they were imbued with a special mission in defense of the Catholic Church, for them threatened by the secularized world.

The neo-reactionary currents are led by the Catholic charismatic movement that brings together an enchanted and magical worldview (the charisms and the Holy Spirit) and the idea of cultural war on the modern world. This action takes place on three fronts: (a) high internal bureaucratization and homogenization, eliminating divergences and dissonant voices; (b) formation of self-centered communities, such as "communities of life and alliance," with strict rules and search for financial self-support; and (c) the election of political senators to the state power, based on the strategies allowed by representative-liberal democracy. The more traditional 
reactionary movements, such as the TFP, however, seem to act more on the first two fronts of this anti-modern and illiberal action. ${ }^{28}$

The neo-reactionary currents are led by the Catholic charismatic movement which brings together an enchanted and magical worldview (the charisms and the Holy Spirit) and the idea of cultural war on the modern world. This action takes place on three fronts: (a) high internal bureaucratization and homogenization, eliminating divergences and dissonant voices; (b) formation of self-centered communities, such as life and covenant communities, with strict rules and seeking financial self-support; and (c) the election of political senators to the state power, based on the strategies allowed by representative-liberal democracy. The more traditional reactionary movements, such as the TFP, however, seem to act more on the first two fronts of this anti-modern and illiberal action.

The resignation of Benedict XVI and the papacy of Bergoglio brought, however, great questions to them. Pope Francis' new emphases on the issue of poverty, love of neighbor, mercy, and dialogue, with strong criticisms of the market economy, have created a deep unease among and within these groups. But these groups continue to develop intense activities, insisting on masses in Latin (Tridentine rite) and seeking to expand their self-reproduction. A question to be deepened is how Pope Francis will act in relation to these groups that build, for themselves and for the religious community, a warrior church against the modern world. One of the forms of papal action is to reduce their internal influence field, through long-term actions or to carry out specific interventions in the short term. Judging by the papal intervention in the Legionnaires of Christ and Heralds of the Gospels, involved in lawsuits and accusations of sexual and moral abuse and by symbolic actions that destroy the anti-modern cultural war, as shown by the recent encyclicals Laudato Sì and Fratelli Tutti and the transnationalization of the College of Cardinals demonstrate this, it is possible that both strategies are underway.

\section{References}

Antoine C (1980) O integrismo brasileiro. Civilização Brasileira, Rio de Janeiro

A missa de São Pio V (2005) Texto da Bula Quo Primum Tempore. Comentário histórico e canônico do Pe. Raymond Dulac. Permanência, Niterói

Azzi R, (1994) A neocristandade: um projeto restaurador. Paulus, São Paulo.

Almeida, R (2019) Bolsonaro Presidente: Conservadorismo, evangelismo e a crise brasileira. Novos Estudos Cebrap. São Paulo, 38/1, pp 185-213, jan.-abr.

Antoine C (1980) O integrismo brasileiro. Rio de Janeiro, Civilização Brasileira

\footnotetext{
28 Observa-se, por exemplo, a atuação da TFP nos Estados Unidos da América e seu esforço em se articular com outros movimentos conservadores naquele país que possuiriam convergências ideológicas e propósitos semelhantes, especialmente no que tange as questões que giram em torno da liberalização dos costumes.

One can observe, for example, the performance of the TFP in the USA and its effort to articulate with other conservative movements in that country that would have ideological convergences and similar purposes, especially regarding issues revolving around the liberalization of customs (Gama; Coppe Caldeira 2018, p.313).
} 
Azzi, R (1977) Catolicismo Popular e Autoridade Eclesiástica na Evolução Histórica do Brasil. Religião e Sociedade, Rio de Janeiro, n. 1, pp 125-149.

Betto F (1985) O que é Comunidade Eclesial de Base. Brasiliense, São Paulo

Boff L (1981) Igreja, carisma e poder. Vozes, Petrópolis

Boff L (1998) O Caminhar da Igreja com os oprimidos: do Vale de Lágrimas à Terra Prometida. Vozes, Petrópolis

Beozzo J (1984) A Igreja entre a Revolução de 1930, o Estado Novo e a Redemocratização. In: Fausto, B (org.). História Geral da Civilização Brasileira (tomo III). Difel, São Paulo

Carranza B (2000) Renovação Carismática Católica: origens, mudanças e tendências. Editora Santuário, Aparecida

Coppe Caldeira R (2011) Os baluartes da tradição: o conservadorismo católico brasileiro no Concílio Vaticano II. CRV, Curitiba

Camargo, C P (1971) Igreja e desenvolvimento. São Paulo, CEBRAP/Editora Brasileira de Ciências.

Camargo, C P (1973) Católicos, protestantes, espíritas, Petrópolis, Vozes

Camurça, M A (2011) Cosmologia e estrutura de longo curso do catolicismo na dinâmica da modernidade. Horizonte: Revista de Estudos de Teologia e Ciências da Religião (Online), v. 09, pp $746-762$.

Dumont L (1979) Homo hierarchicus: Essai sur le système des castes. Gallimard, Paris

Dumont L (1992) Essays on individualism: modern ideology in anthropological perspective. Chicago Press, Chicago

Faggioli M (2012) True reform: liturgy and ecclesiology in Sacrosanctum Concilium. Pueblo Books, Collegeville

Gutiérrez G (1979) Teologia da Libertação. Vozes, Petrópolis

Hunter J (1991) Cultural wars: the struggle to define America. Basic Books, New York

Iglésias F (1971) Estudo sobre o pensamento reacionário: Jackson de Figueiredo. In: Iglésias F (ed) História e ideologia. Perspectiva, São Paulo, pp 109-158

Lima A (1943) O Cardeal Leme: um depoimento. José Olympio, Rio de Janeiro

Löwy M (2000) A guerra dos deuses: religião e política na América Latina. Vozes, Petrópolis

Maia P (1992) História das Congregações Marianas no Brasil. Loyola, São Paulo

Mattei R (1996) O cruzado do século XX: Plínio Corrêa de Oliveira. Civilização, Porto

Moura O (1978) Ideias católicas no Brasil: direções do pensamento católico no Brasil no século XX. Convívio, São Paulo

Oliveira P (1943) Em Defesa da Ação Católica. Ave Maria, São Paulo

Pierucci A (1987) As bases da nova direita. Novos Estudos, CEBRAP, São Paulo 19:26-45

Prandi R (1997) Um sopro do espírito: a renovação conservadora do catolicismo. Edusp/Fapesp, São Paulo

Procópio C (2015) Quando a religião fica perto da política: o caso dos candidatos apoiados pelo catolicismo carismático nas eleições de 2014 no Brasil. Debates Do NER 27:199-232

Procópio C (2019) O catolicismo carismático no impeachment de Dilma Rousseff. Contemporânea Revista De Sociologia Da UFSCAR 9:275-299

Silva E, Silveira E (2020) Quando a religião (des)comunica a ciência: o catolicismo brasileiro e a pandemia de Covid-19. Revista Dispositiva. https://doi.org/10.5752/P.2237-9967.2020v9n16p 188-206

Silveira E (2019) Padres conservadores em armas: o discurso público da guerra cultural entre católicos. Reflexão 43:289-309

Zanotto G (2012) TFP. Tradição, Família e Propriedade. As idiossincrasias de um movimento católico no Brasil (1960-1995). Méritos, Passo Fundo

Lima, L de Souza. Plínio Corrêa de Oliveira. Um cruzado no século XX. Dissertação (Mestrado em História) - Universidade de São Paulo (USP), São Paulo, 1984

Machado, M (1996) Carismáticos e pentecostais: adesão religiosa na esfera familiar. Autores Associados/Anpocs Campinas/São Paulo

Oliveira P, Solimeo G, Solimeo L (1982) As CEBs... das quais muito se fala, mas pouco se conhece. A TFP as descreve como são. Vera Cruz, São Paulo

Pátaro C, Mezzomo F, Sexugi F (2019) "Novamente aqui em união": o grupo de oração beata Elena Guerra e os deputados carismáticos no Congresso Nacional. Revista Pós Ciências Sociais, Programa de Pós-Graduação em Ciências Sociais da UFMA. http://www.periodicoseletronicos.ufma.br/index. php/rpcsoc/article/view/13245 
Reis M (2011) Política e religião: o envolvimento dos católicos carismáticos na política brasileira. 2011. Dissertação (Mestrado em Ciência Política) - PPGCP/UFSCAR, São Carlos

Rifan F (2005) Orientação Pastoral. O Magistério Vivo da Igreja. s/e, 2005, Campos dos Goytcazes

Silveira E (2008a) Corpo, emoção e rito: antropologia dos carismáticos católicos. Armazém Digital: 2008. Available via https://www.academia.edu/43280633/Corpo_emo\%C3\%A7\%C3\%A3o_e_rito_ antropologia_dos_carism\%C3\%A1ticos_cat\%C3\%B3licos

Silveira E (2008b) Terços, "santinhos" e versículos: A relação entre católicos carismáticos e a política. Rever - Revista de Estudos da Religião, São Paulo, PUC-SP, ano 8, p. 54-74, mar. 2008. Available via: https://www.pucsp.br/rever/rv1_2008/t_silveira.pdf

Lima, L S (1984) Plinio Corrêa de Oliveira. Um cruzado do século XX. Dissertação (mestrado em História) - Universidade de São Paulo

Montero, P (1999) Religiões e dilemas da sociedade brasileira Em Miceli, S. (org.) O que ler na ciência social brasileira (1970-1995). São Paulo, Sumaré/Anpocs, pp 327-367

Pierucci, A F (1992) Fundamentalismo e integrismo: os nomes e a coisa. Revista USP. 13 (maio 1992), 144-156. https://doi.org/10.11606/issn.2316-9036.v0i13.

Pierucci, A F (2004) 'Bye bye, Brasil': o declínio das religiões tradicionais no Censo 2000. Estudos Avançados [online]. v. 18, n. 52 [Acessado 13 Setembro 2021], pp 17-28. https://doi.org/10.1590/ S0103-40142004000300003

Romano, R (1979) A Igreja contra o Estado. São Paulo: Kairós.

Romero, C et al (2019-2020) ¿Tradicionalismos, fundamentalismos, fascismos? El avance de los conservadurismos en América Latina Encartes, v. 2, n. 4, septiembre 2019-marzo 2020, pp 252-283 https://encartesantropologicos.mx/religionconservadurismo-americalatina/

Pierre Sanchis, 1992 J F (org.) (1992) Catolicismo: unidade religiosa e pluralismo cultural. São Paulo: Loyola

Pierre Sanchis, J F (1993) Catolicismo, entre a tradição e modernidades. Comunicações do Iser, Rio de Janeiro, v. 44, pp 9-24.

Villaça, A C (1975) O pensamento católico no Brasil, Rio de janeiro: Zahar

Seiblitz, Z M L (1991) Os arquitetos do paraíso. Tese (Doutorado em Antropologia Social) - Museu Nacional da UFRJ.

Publisher's Note Springer Nature remains neutral with regard to jurisdictional claims in published maps and institutional affiliations. 